\title{
Jole Rider and bicycles for Africa
}

\section{Simon Lenton}

Education is the most powerful way to change the world.

Nelson Mandela

Getting children to school is vital.

As you read this, I may be dismantling, cleaning and reassembling the bottom bracket of a bicycle at Gunjur Upper Basic School in The Gambia. Surrounding me is an enthusiastic group of four girls and four boys who, with two teachers, are watching my every move, as they train to become mechanics for the fleet of 100 bicycles their school is about to receive (figs 1 and 2).

It is hot, the sky is visible through the roof, the classroom furniture is sparse and in poor repair but on the wall is the school motto: "Education for all, especially women and children". Outside, dozens of pairs of interested eyes are peering through the 3inch mesh which forms the windows.

For these budding cycle mechanics, the high point of the day will be the race between school teams (fig 3).

First, they cycle round the school. They then return to the classroom, take out the inner tubes from the wheels and run round the school carrying the tubes, then it's back to the classroom, where they reassemble the bicycles ready for one last circuit round the school again. The screams of delight and encouragement will attract passers-by and spontaneous singing and dancing will break out after the race.

For me, the high point will be sitting with the children at the end of the day, sharing a large bowl of rice and fish, hearing about their lives and their aspirations, knowing that just maybe a few more will now have the benefit of education.

This is all part of the work of Jole Rider, ${ }^{1}$ a small Bath-based charity, which was born in 2004 after a chance conversation with a head teacher in The Gambia who explained that he could not afford to repair the donated school bus which had broken down. As a result, children from farflung villages were not getting to school and he was concerned for their future.

Meanwhile, back in the UK, serviceable bicycles are thrown away every day - so the idea to recycle cycles was born. Not a new idea, but if it was to truly succeed in

Correspondence to: Simon Lenton, Child Health Department, Newbridge Hill, Bath BA1 30E, UK; simon.lenton@banes-pct.nhs.uk the long term the programme needed to be simple, replicable and sustainable.

There are too few secondary schools in The Gambia, so they are used by two shifts of children per day, which means some children have to walk up to 10 miles each way. It is estimated that 50000 children do not get to school, ${ }^{2}$ partly because of the distances involved.

The donated bicycles become the property of the school parent-teacher association, so that they are passed from one generation of children to the next. Bicycles are provided to the children with the longest distances to travel, and a school-parent contract ensures improved attendance.

If children with bicycles are persistently late, the bicycle is given to another child. At the school's suggestion a small charge is made for the hire of the bicycle to cover the ongoing maintenance costs. Already, participating schools are reporting better attendance and improved exam results.

I spent my student elective period at the Medical Research Council field stations in Fajara and Keneba, The Gambia in 1976. My lasting memory was of a remarkably happy nation despite all the extremes of poverty and high mortality rates.

It was the start of my public health interests and the realisation that most modern medicine is irrelevant unless the basics - clean water, sanitation, adequate nutrition, all within a politically stable society - are first attended to. I also began to realise that many "aid projects" could undermine local self-sufficiency, with food aid undercutting local production, equipment from developed countries merely supporting the donor economy and few projects being truly sustainable after the end of the funding period.

Returning 30 years later, my immediate impressions were of deforestation and loss of birdlife, westernisation of dress and the use of mobile phones, but most villages still do not have electricity, sanitation has not improved and many continue to rely on open wells for their water supply.

Globally, since 1976, there has been a growing awareness of the impact of human activity in depleting natural resources (mainly trees and fossil fuels), the creation of ever greater inequalities both within and between nations and the generation of unsustainable levels of pollution (mainly carbon dioxide) - now called human-induced global climate change. ${ }^{4}$

This problem is primarily driven by a free market economy that largely values profit over any concern for negative social or environmental impacts of business activity. Above a certain point, increased consumption of resources does not improve health, indeed inequalities increase and quality of life decreases. Meanwhile, the less developed world suffers most of the consequences of climate change that creates extremes of weather and slowly increasing sea levels, which will affect millions of people living in coastal areas in the poorest parts of the world. ${ }^{5}$

Faced with this potential impending global catastrophe, how should paediatricians respond $?^{6}$ David Baum, past president of the RCPCH and chairman of the British Association for Community Child Health (BACCH), would retell the starfish story as his philosophy and as a result, the starfish emblem was adopted as the logo for the BACCH Newsletter chairman's column?:

\section{As the old man walked the beach at dawn, he noticed a young man ahead of him picking up starfish and flinging them into the sea. Finally catching up with the youth, he asked him why he was doing this. The answer was that, the stranded starfish would die if left in the morning sun. "But the beach goes on for miles and there are millions of starfish," countered the other, "how can your effort make any difference?" The young man looked at the starfish in his hand and then threw it into the safety in the waves, "It makes a difference to this one", he said. \\ Adapted from The Star Thrower by Loren Eiseley}

I have always been haunted by this story. Saving one child's life in the face of huge natural disasters, famine or civil unrest seems futile, but if we don't care about one child, how can we care about humanity?

A similar tension exists between our responsibilities as paediatricians to an

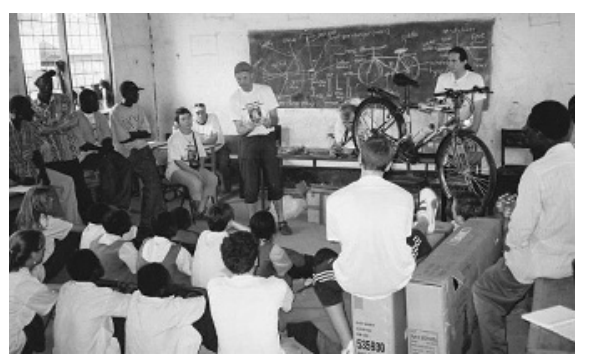

Figure 1 Bicycle training in progress. 


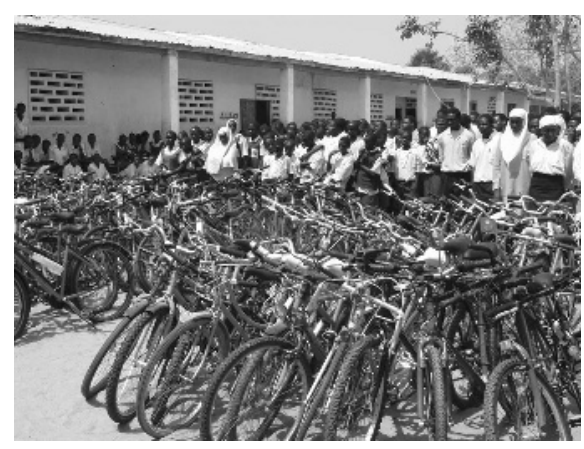

Figure 2 Bicycle handing-over ceremony.

individual child and our roles as advocates for a population of children. Resources will always be finite: the key question is how best to use available resources to achieve the best health for the greatest number of children.

Similar questions have to be asked about aid programmes and charitable giving - do they really achieve their goals or should we seek alternative models? My public health training makes me always ask, "Where is the weakest link in the system?" because focusing on that point identifies where the real gains can be made. The best solutions should act as catalysts and must always be both achievable and sustainable.

A successful model that is emerging for Jole Rider is a partnership between a secondary school (and their feeder primary schools) together with a local business in the UK and a secondary school in The Gambia. The initial commitment is to collect and service 400 bicycles and raise $£ 4000$ for tools, spares and transportation costs.

Jole Rider also provides opportunities for a group of young people to visit Africa and provide bicycle maintenance training in schools. Visiting an African school is a real eye-opener for them. Classrooms with only a blackboard, libraries without books, workshops without tools, and often donated computers without electricity! Amazingly, all the children and teachers are really committed to learning.

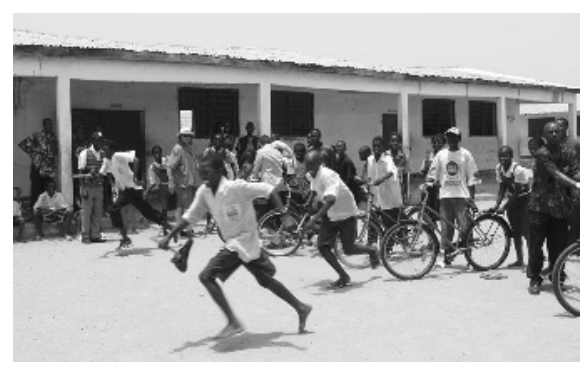

Figure 3 Round the school bicycle races.
For these young people, UK "waste" suddenly becomes a resource - books, hand tools, sewing machines, garden tools, mobile phones are all valuable, and low-cost items such as pens, paper and toys (none of which can be produced in The Gambia) are real assets.

The experience has transformed those young people who have been involved. For them Africa is no longer a distant and scary place - teenagers there just want to learn, enjoy football and music, make friends and have fun. International links for schools are being actively promoted in the UK by the Department of Children, Schools and Families through the International School Award. ${ }^{8-10}$

\section{WHAT OF THE FUTURE?}

The combination of a school, with local business support, linking with schools and communities in the developing world is potentially a powerful one. It combines learning and entrepreneurship with practical action and reducing inequalities. Future sea containers might contain a "sustainable schools" pack - based on local needs consisting of recycled bicycles, reading and text books, hand tools, garden tools and hand sewing machines with some new materials such as roofing sheets to keep the books dry (and may be a few footballs and even some team shirts!). All eminently achievable and within the capacity of an average school.

There is increasing recognition of the plight of people living in sub-Saharan Africa and the importance of long-term sustainable solutions rather than shortterm crisis relief, the Katine project supported by the Guardian newspaper being a recent example - do watch the video clips that are so representative of life in many parts of Africa. ${ }^{11}$

Bicycle programmes not only get children to school but can get goods to market, water to homes and people to work while saving people both time and money (fig 4). The business of refurbishing, adapting and repairing bicycles can also contribute to poverty reduction, encourage sustainable development and help reduce pollution. ${ }^{12-15}$ Similar schemes are equally applicable in the UK by encouraging less dependence on fossil fuels, encouraging healthy exercise and benefiting the least well-off in society. ${ }^{16}{ }^{17}$

However, education remains the key, and linking schools with charities and local businesses, to schools around the world to provide local support and practical solutions, such as composting toilets, tube wells and solar power, appears both achievable and sustainable. ${ }^{18}$ In my experience the

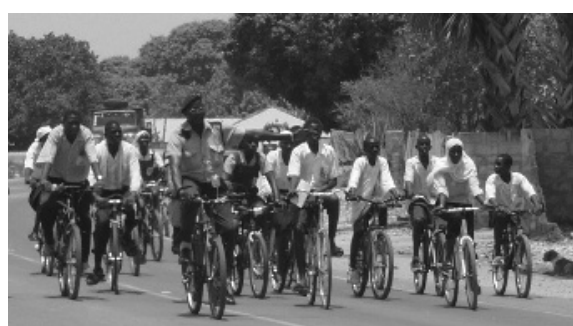

Figure 4 First ride - with police supervision.

insights of children in Africa are often profound, exemplified by Aminata Palmer, who survived civil war in Sierra Leone to emerge as a United Nations ambassador ${ }^{19}$ :

I would like to say to the world leaders: please understand that you are representing the world. Any decisions you take will not only affect your own country but the world at large. So be wise to make sure that you mention children when discussing issues. Children should always come to the top of your agenda because they are your future. UN ambassador Aminata Palmer (11), Sierra Leone

Photo credits: Peter Benning, Simon Lenton, Richard Fairman.

Accepted 27 November 2007

Arch Dis Child 2008;93:439-441.

doi:10.1136/adc.2007.122671

\section{REFERENCES}

1. Jole Rider. www.jole1000.org laccessed 21 January 2008).

2. Daily Observer, The Gambia, February 2005

3. MRC Laboratories, The Gambia. http:// www.mrc.gm/ (accessed 21 January 2008).

4. HM Treasury. Stern review on the economics of climate change. http://www.hm-treasury.gov.uk/ independent_reviews/

stern review economics climate change/ stern_review_report.cfm (accessē 21 January 2008).

5. Intergovernmental Panel on Climate Change. Climate change 2007 (in three parts). (a) Working group I report: The physical science basis. (b) Working group II report: Impacts, adaptation and vulnerability. (c) Working group III report: Mitigation of climate change. http://www.ipcc.ch/ipccreports/ar4-wg1.htm (accessed 21 January 2008).

6. Waterston A, Lenton S. Public health: sustainable development, human induced global climate change. Arch Dis Child 2000;82:95-7.

7. British Association for Community Child Health www.bacch.org.uk (accessed 21 January 2008).

8. Department for Children, Schools and Families International strategy \& programmes. http:// www.dfes.gov.uk/internationalstrategyprogrammes/ (accessed 21 January 2008).

9. British Council. Welcome to the International School Award. http://www.britishcouncil.org/learninginternational-school-award.htm laccessed 21 January 2008).

10. Global Gateway. http://www.globalgateway.org.uk/ (accessed 21 January 2008).

11. Guardian Unlimited. Katine - it starts with a village http://www.guardian.co.uk/katine laccessed 21 January 2008).

12. Re-cycle. Fighting poverty with affordable transport. http://www.re-cycle.org/. (accessed 21 January 2008)

13. Pedals for Progress. http://www.p4p.org/ laccessed 21 January 2008). 
14. AfrbikeNet. Pan-African bicycle information network. http://groups.yahoo.com/group/AfrBikeNet/ (accessed 21 January 2008)

15. Vélo Mondial. The global master plan for cycling. http:// www.velomondial.net/ (accessed 21 January 2008).
16. Bikeforall. Re-cycle your cycle. http://www.bikeforall. net/linkcat.php?cid $=64$ (accessed 9 February 2008)

17. Community Can Cycle. http://www.

communitycancycle.org.uk/ (accessed 21 January 2008)

18. Practical Action. http://practicalaction.org/ (accessed 21 January 2008).

19. UNICEF. Voices of youth. http://www.unicef.org/voy/ takeaction/takeaction 3174.html laccessed 21 January 2008)

\section{Images in paediatrics}

\section{Intrabiliary rupture of hydatid cyst demonstrated by magnetic resonance cholangiopancreatography}

A 13-year-old girl presented with right hypochondriac pain associated with fever, rigors and chills. Physical examination was remarkable for mild icterus, pyrexia (high grade) and tender hepatomegaly. Laboratory investigations revealed leucocytosis with neutrophilia, elevated serum bilirubin levels, mild elevation of transaminase levels and marked elevation of alkaline phosphatase. Ultrasound examination of the abdomen revealed a large cyst in the right lobe of the liver with multiple peripheral daughter cysts, with a smaller left lobe cyst. Intrahepatic biliary radicals were grossly dilated with debris and few membrane fragments in the common hepatic duct; common bile duct (CBD) was not optimally visualised. As such, magnetic resonance imaging with magnetic resonance cholangiopancreatography of the patient was performed. A large hydatid cyst was seen in right lobe of the liver with multiple peripheral daughter cysts and a smaller cyst in left lobe of the liver. The intrahepatic biliary radicals were dilated with gross distention of the gall bladder. Multiple linear hypointense membranes were seen in the intrahepatic biliary radicals (IHBR), common hepatic duct (CHD) and most prominently in dilated CBD. The pancreatic duct was not dilated. The visualisation of cystic membranes in the $\mathrm{CBD}$ and $\mathrm{CHD}$ was more obvious on the heavily T2 weighted source half acquisition single shot turbo spin echo (HASTE) images, and less obvious on the maximum intensity projection (MIP) images.

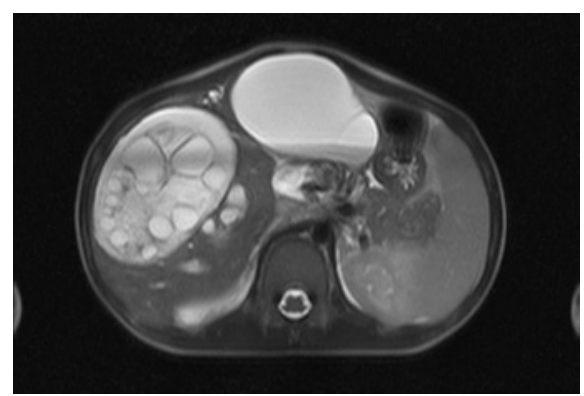

Figure 1 T2 weighted coronal HASTE images showing a large right lobe cyst with multiple daughter cysts inside. Membranes are seen in the biliary channels and the CBD (arrow). The gall bladder (GB) is distended. (T2 HASTE Tra gated TE 85,TR 1150)
Endoscopic retrograde cholangiopancreatography was subsequently performed, with retrieval of multiple membranes from the $\mathrm{CBD}$.

\section{DISCUSSION}

Ultrasound is the most frequent technique employed in the diagnosis of hepatic hydatid cysts. The various appearances by ultrasound include a unilocular cyst, a cyst with daughter cysts producing a multiseptate or a cartwheel appearance and a multivesicular cyst with heterogenous echogenic interior. ${ }^{1}$ A ruptured cyst may show undulating membranes inside. The sensitivity of ultrasound for diagnosis of intrabiliary rupture is $66-94 \%,{ }^{2}$ and the accuracy is increased if CT is also employed. ${ }^{3}{ }^{4}$ Contrast enhanced computed tomography reveals hydatids as cysts with wall enhancement as well as enhancement of internal septae; calcification is also easily demonstrated..$^{5}$ Rupture into the biliary channels is suggested by dilation of CBD with low attenuation material inside. Cyst-wall discontinuity, a direct sign of rupture, is seen in three our of four cases. ${ }^{3}$ The accuracy of CT and ultrasound together is $100 \%$ in cases with uncomplicated biliary rupture. ${ }^{7}$

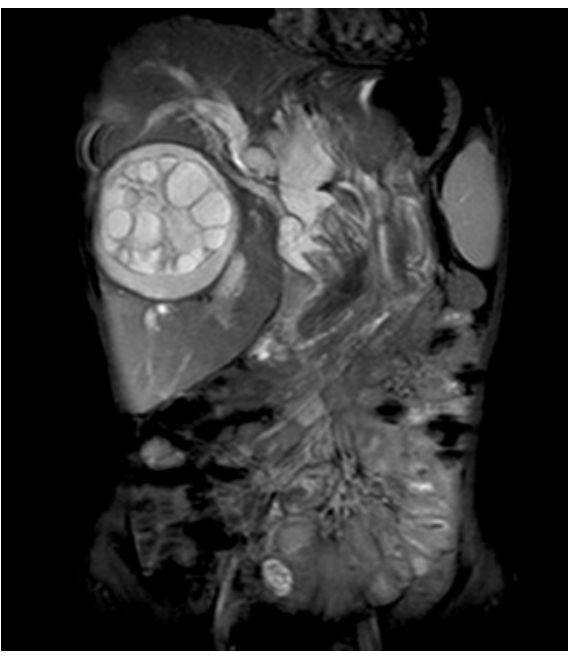

Figure 2 T2 Weighted trufi (true fast imaging with steady precession (FISP)) coronal breathhold images show a right lobe hydatid cyst with multiple daughter cysts with dilated biliary channels and multiple hypointense membranes filling the distal CBD (arrow). (T2 Weighted Trufi TE 2.15,TR 4.3)

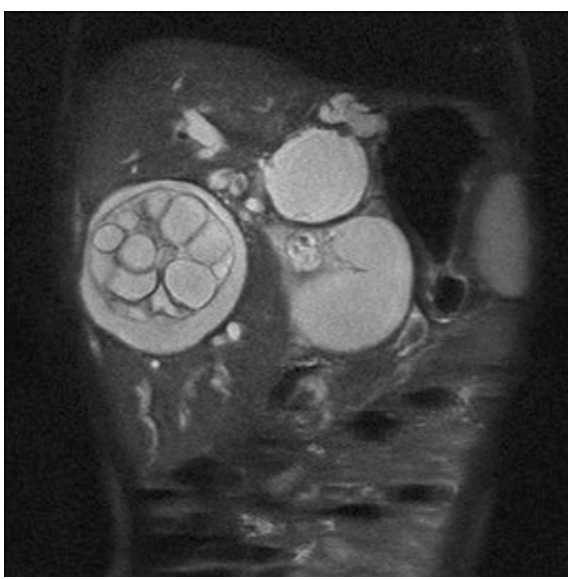

Figure 3 T2 Weighted trufi (true fast imaging with steady precession (FISP)) coronal breathhold images showing multiple hypointense membranes filling the biliary channels.

ERCP not only has a definitive diag nostic role but also has a therapeutic one. The membranes protrude out from the papilla of vater; dilated ducts with debris and daughter cysts appear as radiolucent filling defects.

Our case emphasises the usefulness of MRI in showing that the membranes in the biliary channels and $\mathrm{CBD}$ are a cardinal manifestation of intrabiliary rupture.

\section{Naseer A Choh, ${ }^{1}$ Suhil A Choh, ${ }^{2}$ Majid Jehangir $^{1}$}

${ }^{1}$ Department of Radiology, Shri Maharaja Hari Singh Hospital, Srinagar, India; ${ }^{2}$ Department of Pediatrics, Sheri Kashmir Institute of Medical Sciences Soura, Srinagar, India

Correspondence to: Dr Suhil A Choh, House No.E-12, Coperative Colony, Pirbagh, Srinagar, India; suhilchoh@ rediffmail.com

Arch Dis Child 2008;93:441. doi:10.1136/adc.2008.138354

\section{REFERENCES}

1. Fernando C. Gonzalo S, Ricardo R, et al. Ultrasound diagnosis of ruptured hydatid cyst of the liver with biliary obstruction. Gastrointest Radiol 1986;11:330-3

2. Kumar R, Reddy SN, Thulkar S. Intrabiliary rupture of hydatid cyst: diagnosis with $\mathrm{M} \mathrm{RI}$ and hepatobiliary isotope study. Br J Radiol 2002;75:271-74.

3. Marti-Bonmati L, Menor F, Ballesta A. Hydatid cyst of the liver: rupture into the biliary tree. AJR 1988;150:1051-3.

4. Lewall DB, McCorkell SJ. Rupture of echinococcal cysts:diagnosis, classification and clinical implications. AJR 1986;146:391-4.

5. Lewall DB, Nyak P. Hydatid cysts of the liver: two cautionary signs. Br J Radiol 1998;71:37-41.

6. Taourel P, Marty-Ane B, Charasset S, et al. Hydatid cyst of the liver: comparison of CT and MRI. J Comput Assist Tomogr 1993;17:80-5.

7. Kornaros SE, Aboul-Nour TA. Frank intrabiliary rupture of hydatid hepatic cyst: diagnosis and treatment. J Am Coll Surg 1996;183:466-70.

8. Pedrosa I, Saiz A, Arrazola J, et al. Hydatid disease:radiologic and pathologic features and complications. Radio Graphics 2000;20:795-817. 